Article

\title{
The Informational Consequences of Populism: Social Media News Use and "News Finds Me" Perception
}

\author{
Pablo González-González ${ }^{1, *}$, Hugo Marcos-Marné ${ }^{1}$, Iván Llamazares ${ }^{1}$, and Homero Gil de Zúñiga ${ }^{1,2,3}$ \\ ${ }^{1}$ Democracy Research Unit, University of Salamanca, Spain \\ 2 Department of Film Production and Media Studies, Pennsylvania State University, USA \\ ${ }^{3}$ Department of Communication, Universidad Diego Portales, Chile \\ * Corresponding author (pablogglz@usal.es)
}

Submitted: 30 July 2021 | Accepted: 5 October 2021 | Published: 17 February 2022

\begin{abstract}
Prior studies have theorized a positive association between people's populist attitudes and an increased use of social media to consume news, which will be mainly driven by individuals' engagement with news that reflects their people-centered, anti-elitist, and Manichean understanding of politics. However, such general connection remains elusive. This research seeks to further clarify this strand of the literature by incorporating people's belief that important political information will find them without actively seeking news-"News Finds Me" perception (NFM). For that, we use online survey data from two European countries that differ regarding the ideological political supply side of populism (Italy and Portugal). The main results suggest that citizens who hold stronger populist attitudes will also develop stronger NFM. Furthermore, findings reveal a mediating effect of social media news use on the effects of populist attitudes over NFM. That is, those who hold stronger populist attitudes tend to use social media to get exposed to public affairs news more often, which in turn explains the development of the NFM. These results emphasize the importance of systematically exploring citizens populists' attitudes within today's social media, social networks, and complex information systems.
\end{abstract}

\section{Keywords}

Europe; News Finds Me perception; news use; populism; social media

\section{Issue}

This article is part of the issue "Analyzing Citizen Engagement With European Politics Through Social Media" edited by Pieter de Wilde (Norwegian University of Science and Technology), Astrid Rasch (Norwegian University of Science and Technology), and Michael Bossetta (Lund University).

(C) 2022 by the author(s); licensee Cogitatio (Lisbon, Portugal). This article is licensed under a Creative Commons Attribution 4.0 International License (CC BY).

\section{Introduction}

Scholars' interest in the relationship between populism and social media seems logical considering the rapid (re)emergence of populist forces around the globe and the pervasive use of social media across countries. While abundant approaches to this topic exist (Engesser et al., 2017; Ernst et al., 2019; Jeroense et al., 2021; Müller \& Schulz, 2021; Rae, 2021; Reinemann et al., 2016; Schulz, 2019; Stier et al., 2020), two main broad questions seem to be attracting academic attention. First, do populist politicians use social media more often to spread their messages? And second, do populist indi- viduals consume political news from social media to a greater extent? This article looks to shed light on the latter, for which it puts together the concepts of populist attitudes, social media news use, and the "News Finds Me" perception (NFM). Studying this connection will help us explain why certain individuals are more prone to think that news will reach them without an active effort from their side, contribute to clarifying the levels and types of social media political engagement as a function of individuals' populist attitudes, and improve our understanding of the electoral success of populist politicians that recur to social media to spread their political discourse. 
Overall, empirical studies have found no straightforward relationship between populist attitudes and social media use in comparative terms (Jeroense et al., 2021; Schulz, 2019; Stier et al., 2020). While a general expectation existed that populist people will use social media more often, such theoretical assumption remains empirically elusive. Political communication findings point out the importance of considering different social media and different patterns of use to understand whether and how individuals ranking higher on populist attitudes use more social media, especially for news. Besides further exploring the general connection with new data, this article takes a step back and explores whether demand-side populism correlates with the perception that information will come from peers, often from social media, without much active effort involved. That is, with people's perception that they can remain well-informed about public affairs without actively seeking news, as the news will find them anyway through peers and social networks: NFM (Gil de Zúñiga et al., 2017). For that, we ask about the association between populist attitudes and social media news use, hypothesize that the NFM perception should be higher for individuals who display stronger populist attitudes, and to complement our first question, explore whether our hypothesized relationship is mediated by general levels of social media news use.

To test our arguments, we build upon an original and demographically diverse survey data collected online in Italy and Portugal, two Southern European countries with a very different situation regarding supply-side populism. While relevant populist parties exist in Italy that compete from different places within the left-right axis (Caiani \& Graziano, 2019), populism has not been so systematically used by political parties in Portugal, and it has been combined more often with left-wing ideologies (Gómez-Reino \& Plaza-Colodro, 2018), at least until the appearance of CHEGA in 2019 (Rooduijn, 2019). More information about our case selection and its implications can be found in the data and methods section.

In line with previous research, we find no conclusive evidence for the association between populist attitudes and social media news in our analysis. However, we find a positive cross-country association between populist attitudes and NFM and support for a mediation mechanism between said variables. These results thus indicate a potential challenge for developing wellinformed debates in contemporary societies, provided that NFM is associated with low levels of political learning (Gil de Zúñiga et al., 2017), and populist attitudes are widespread across countries (Kaltwasser \& Van Hauwaert, 2020). Overall, our findings evidence that the association between demand-side populism and social media may be operating through more intricate pathways than initially expected. They advise for further research considering mediating mechanisms and reinforcing effects. Important in this regard is the dynamic effect of social media news use on the levels of political knowledge displayed by populist individuals and its potential consequences on voting.

\section{Literature Review}

\subsection{Populist Attitudes and Social Media News Use}

Although the literature on populism has experienced a boom in recent years (Mudde \& Kaltwasser, 2018; Rooduijn, 2019), theoretical discussions around the term long predate more recent and more empirical scholarly efforts (Canovan, 2004; lonescu \& Gellner, 1969; Laclau, 2005). In fact, a wide range of definitions of populism exists (Aslanidis, 2015; Dornbusch \& Edwards, 1991; Mudde, 2004; Weyland, 2001), each one with its own emphasis. This is well exemplified in early work by lonescu and Gellner (1969), who spoke of an essentially contested term. However, nowadays, and while the situation has not reached an absolute definition convergence, there is a growing consensus around the ideational approach to populism, especially among political science scholars (Hawkins, Carlin, et al., 2019; Hawkins \& Kaltwasser, 2017; Mudde \& Kaltwasser, 2018).

The ideational approach considers populism as a set of ideas that emphasizes three core components: anti-elitism, people-centrism, and a Manichean outlook of politics (Hawkins, Kaltwasser, et al., 2019). A significant advantage of this ideational approach for empirical studies is that its emphasis on ideas allows considering populism as an ideology or a discourse (Mudde \& Kaltwasser, 2018). A second advantage, crucial for this research, is that populism can be gradually observed from both a demand-and a supply-side perspective. That is, parties and politicians may occupy a space in a continuum between populism and non-populism attending to their discourses, and citizens could also be located at some point of the continuum attending to their preferences regarding anti-elitism, people-centrism, and Manicheism. To put it into different words, populist discourses exist (supply-side), but so do populist attitudes (demand-side; Hawkins, Kaltwasser, et al., 2019).

As scales to measure populist attitudes were refined (Akkerman et al., 2014; Hawkins et al., 2012; Schulz et al., 2018), so did our understanding of their causes and consequences. Populist attitudes have been associated with feelings of deprivation and declinism (Elchardus \& Spruyt, 2016), anger (Rico et al., 2017), ideological radicalism (Marcos-Marne et al., 2021), and have been found to positively predict voting for populist parties (Hawkins, Kaltwasser, et al., 2019; Marcos-Marne, 2020; van Hauwaert \& van Kessel, 2018). However, an ongoing and relevant discussion persists on the connections between populist attitudes and media use. This link is essential as, in the context of social media, the role of news may be to further divide the political realm and society into "us, the people," versus "them, the elites," supporting the way politicians and citizens negotiate important informational resources comprising both supply and demand facets of populism (see an edited volume on populism by Gil de Zúñiga et al., 2020). 
When looking at traditional media, populist attitudes have been associated with a higher likelihood of consuming news, primarily TV and tabloid ones (Schulz, 2019), which gives support to the idea that populist politics can actually be more sophisticated than initially thought (Groshek \& Koc-Michalska, 2017; Stanley \& Cześnik, 2021; van Kessel et al., 2021).On the other hand, the relationship between populist attitudes and social media consumption seems far less clear (Jeroense et al., 2021; Müller \& Schulz, 2021; Schulz, 2019; Stier et al., 2020).

A general expectation in this subfield was that populist individuals would use social media more often, especially to surveil political content, an idea built upon three main components (Jeroense et al., 2021). First, social media facilitates that people connect with like-minded individuals (Wells et al., 2020). Second, social media use speaks well to the dichotomy of people-elites, as it enables an informative space that is not so constrained by the agenda of mainstream media, often distrusted by populist individuals (Fawzi, 2019; Fawzi \& Mothes, 2020; Schulz et al., 2020). Third, populist politicians are often thought to use social media more systematically. Even if this is not unchallenged, the perception that this is true would be enough for populist individuals to turn to social media more frequently (Bucy et al., 2020). However, and as announced before, the general relationship between populist attitudes and social media use continues to remain elusive. Populist attitudes have been found to correlate negatively with social media political use in the Netherlands (Jeroense et al., 2021), and only positively with Facebook usage, rather than Twitter, in a comparative study of 11 countries (Schulz, 2019). Considering there is an interest in the accumulation of empirical material to be able to better understand the relationship described above, including evidence from less scrutinized countries as observations (i.e., Portugal and Italy), we ask again in this article:

RQ1: What is the association between people's populist attitudes and their frequency of social media use for news?

\subsection{Populist Attitudes and News Finds Me Perception}

While the general relationship between demand-side populism and social media is still contested, more populist individuals are nevertheless more likely to use "alternative media with an affinity to populism" (Müller \& Schulz, 2021). This supports the expectation that social media news use of more populist individuals can be conditioned by how they perceive the media environment beyond traditional clear-cut divisions between digital and offline/mainstream sources (Stier et al., 2020). In essence, social media may not be a single homogeneous ecosystem that is consistently more often used by populist people, and different patterns of use with distinct effects may coexist within the general social media network. To shed additional light on the online news pref- erences of individuals with strong populist attitudes, we incorporate the concept of NFM.

NFM reflects the individuals' belief that "they can indirectly stay informed about public affairs through general internet use, information received from peers, and connections within online social networks" (Gil de Zúñiga et al., 2017, p. 3). As such, NFM has been theorized as a higher-order construct with three subdimensions: being informed (epistemic dimension), not-seeking (motivational dimension), and reliance on peers (instrumental dimension; Song et al., 2020). Often seen as a byproduct of media environments with many choices, high levels of NFM do not entail an active avoidance of news. Far from that, individuals ranking high on NFM are particularly receptive to new information gathered using social media, especially when this comes from peers (Gil de Zúñiga et al., 2020). In fact, the NMF's instrumental dimension reflects that people believe they can delegate the acquisition of information to their online and social network peers (Song et al., 2020). It is here that we see the connection with populist attitudes.

First, regarding the instrumental and peer-reliance dimension of NFM, we expect that individuals with stronger populist attitudes will be more likely to agree with the NFM idea that they can rely on their peers to be well-informed. This is so because individuals displaying strong populist attitudes perceive the existence of a homogeneous and kind-hearted group of people that, just like them, are opposed to evil elites, and are more likely to distrust mainstream media (Fawzi, 2019; Fawzi \& Mothes, 2020; Schulz et al., 2020). Second, and tapping into the epistemic (being well-informed) and motivational (not-seeking) dimensions of NFM, we expect that individuals who agree with the Manichean and schematic understanding of politics inherent to populism will also resonate more strongly with the assumption that good/complete information is attainable without looking up for it at all. Therefore, we propose a framework of analysis that identifies key components of populism that are at the core of the NFM perception, expecting that levels of NFM will be influenced by the extent to which individuals agree with the anti-elitist, people-centered, and Manichean understanding of politics. Overall, we see the anti-elitism and people-centrism components of populism more clearly represented in the instrumental dimension of NFM, and the Manichean one in the epistemic and motivational dimensions. To be clear, we do not claim a single causal path between individuals' populism and NFM, but rather a situation of elective affinity between them. Importantly, we believe populist attitudes will antecede NFM (and not the other way around) because of the general understanding of politics that populism entails, connected with the shortcomings of representative democracy (Canovan, 2004), and due to empirical research suggesting the relative stability of populist attitudes, even if they do not always have electoral consequences (Hawkins, Kaltwasser, et al., 2019; Marcos-Marne, 2021). Accordingly, we expect that: 
$\mathrm{H} 1$ : Individuals with stronger populist attitudes will display higher levels of NFM.

To finish this theoretical section, we also consider an additional aspect, which is whether the relationship between populist attitudes and NFM is mediated by social media news use. This is important because previous studies have found social media news use consistently predicts NFM. Individuals ranking high on NFM may be more likely to use social media but using social media for news is a stronger and more powerful predictor of NFM development, according to evidence from longitudinal studies (Gil de Zúñiga et al., 2017). Should we ignore this potential mediating mechanism, we might miss relevant information about the connection between social media news use and the demandside populism. We expect that social media news use will positively mediate the effects of people's populist attitudes over the proliferation of NFM. However, due to the exploratory nature of our approach and looking to shed additional light on the relationship initially set in RQ1, we ask:

RQ2: Is the relationship between populist attitudes and NFM mediated by social media news use?

Overall, our theoretical framework considers literature from communication and political science to shed light on the informational practices of populist individuals. We do that by either asking innovative questions (direct and mediated effects of populist attitudes on NFM) or providing new empirical data to ongoing debates (populist attitudes and social media news use). We believe the responses to these questions will have important implications for at least two relevant lines of research. First, the implication for the role of offline characteristics (among which populist attitudes should be counted) in the levels and types of online political participation. Second, the electoral consequences of populist politicians entering social media, insofar as some of their potential voters might be more likely to be using non-traditional media to get informed.

\section{Data and Methods}

This study relies on original online survey data collected in Italy and Portugal during November 2020 by Netquest, an internet panel provider that works in agreement with the ISO Standard 26362 of panels in market, opinion, and social research. Our two samples (Italy $n=1,000$; Portugal $n=1,055$ ) were drawn aiming for representativeness, accounting for demographic key elements such as age, gender, and territorial location of respondents (quota sampling within an opt-in panel). While we are aware of the potential limitations of online surveys to obtain reliable population estimates, we also acknowledge that some of these issues are not unique to online procedures (e.g., participation biases are also found frequently in offline surveys; Wright, 2005). Furthermore, we focus our analysis on relationships between variables instead in obtaining population estimates, which would be more problematic if deviated samples were obtained (Baker et al., 2010). In short, we adhere to the idea that online surveys are no panacea for researchers. However, they can still be used successfully considering both the goals of each paper and the potential limitations attached. Bearing that in mind, we offer a comparison of key demographic features in our surveys and representative data from the census of the countries studied (Table 1).

Our variables, unless otherwise stated, are measured on 1 to 10 on a Likert scale. To minimize potential measurement error arising from missing data from some subjects, we used multiple imputation at the itemlevel before computing the final constructs of interest (Eekhout et al., 2014; Gottschall et al., 2012). To match the Likert scales, we set the minimum and maximum values per variable and rounded the final imputed values to 1 as constraints during the procedure. Only two variables in both countries suffered from above $10 \%$ missing cases: Ideology (Italy: 16.9\%; Portugal 13.9\%) and Household Income (Italy: 13.7\%; Portugal: 11.9\%), and both perform as controls in our analyses. Five imputations were generated in SPSS using the Markov chain Monte Carlo (MCMC) method (MacKay \& Mac Kay, 2003;

Table 1. Comparison of our samples and country census considering the quota-sampling criteria.

\begin{tabular}{|c|c|c|c|c|}
\hline \multirow[b]{2}{*}{ Variable } & \multicolumn{2}{|c|}{ Italy } & \multicolumn{2}{|c|}{ Portugal } \\
\hline & Our sample & Census & Our sample & Census \\
\hline Sex (females) & $52 \%$ & $52 \%$ & $45 \%$ & $53 \%$ \\
\hline Age (mean) & 51 & 46 & 50 & 46 \\
\hline \multicolumn{5}{|l|}{ Education } \\
\hline Less than primary, primary, and lower secondary education & $48.6 \%$ & $39.6 \%$ & $47.6 \%$ & $55 \%$ \\
\hline Upper secondary, post-secondary non tertiary education & $36.5 \%$ & $42.8 \%$ & $28.7 \%$ & $23.8 \%$ \\
\hline Tertiary education & $14.9 \%$ & $17.6 \%$ & $23.7 \%$ & $21.2 \%$ \\
\hline
\end{tabular}

Notes: Italy's census data collects people from the age of 15 and older. Our sample, from 18 and older. Sources: Istituto Nazionale di Statistica (n.d.); for Portugal's census data see Conselho Nacional de Educação (n.d.); Instituto Nacional de Estatística (n.d.). 
Schafer, 1999). Guided by summaries on the missingness in the data and the imputation procedure, all analyses in Section 4 were conducted over the third imputation dataset.

\subsection{Independent, Mediating and Criterion Variables}

This study's independent variable of interest is populist attitudes. Following previous research (Akkerman et al., 2014; Silva et al., 2020), we utilized a six-item construct that averages respondents' agreement with the questions reported in Table 2, measured in a Likert scale from 1 to 5 (Italy: Cronbach's $\alpha=.82 ; M=3.78 ; S D=0.72$; Portugal: $\alpha=.75 ; M=3.71 ; S D=0.70)$.

Social media news use is used as a dependent and mediating variable. To measure it, respondents were asked four questions about the frequency by which they use social media platforms to acquire news (Facebook, Twitter, WhatsApp, and others such as Instagram or YouTube) and a broader question asking for their general social media news use (Italy: Cronbach's $\alpha=.78 ; M=4.93$, $S D=2.35$; Portugal: $\alpha=.77 ; M=4.09, S D=2.11$ ).

NFM is the main criterion variable of the study. Following previous research (Gil de Zúñiga \& Cheng, 2021; Song et al., 2020), we measured respondents' perception of being well-informed about current news and public affairs without any effort as the news will eventually reach them, by means of a six-item construct. This construct averages the following questions: "I rely on my friends to tell me what's important when news happens," "I can be well informed even when I don't actively follow the news," "I do not worry about keeping up with news because I know news will find me," "I rely on information from my friends based on what they like or follow through social media," "I do not have to actively seek news because when important public affairs break, they will get to me in social media," and "I'm up-to-date and informed about public affairs news, even when I do not actively seek news myself" (Italy:
Cronbach's $\alpha=.81 ; M=5.09 ; S D=1.89 ;$ Portugal: $\alpha=.78$; $M=4.88 ; S D=1.68)$.

\subsection{Control Variables}

Regarding political antecedents, we controlled for leftright ideology $(1=$ left, $10=$ right; Italy: $M=5.77$, $S D=2.73$; Portugal: $M=5.07, S D=2.26)$, political interest (Italy: $M=2.57, S D=0.86$; Portugal: $M=2.67, S D=0.79$ ), and political trust (Italy: Cronbach's $\alpha=.89, M=4.27$, $S D=1.97$; Portugal: $\alpha=.87, M=4.38, S D=1.77)$. The latter construct averages respondents' degree of trust in the following institutions: The "Parliament," the "political class," "political parties," "President of the Republic" (question not included in Portugal), "armed forces," and the "European Parliament." For media antecedents, we controlled for traditional news use, which averages respondents' use of TV, newspapers, radio, and online media for news (seven items in total; Italy: Cronbach's $\alpha=.79 ; M=6.37, S D=1.91$; Portugal: $\alpha=.78 ; M=6.14$, $S D=1.78)$. Last, we controlled for a set of sociodemographic variables referring to respondents' age, gender, education, and household income.

To unravel the proposed theoretical connections, we conducted a set of hierarchical Ordinary Least Squares (OLS) regressions, one per country (Italy and Portugal), and a third one with pooled data from both countries. Finally, we conducted a regression-based mediation analysis over the pooled data to estimate whether there is an indirect effect of the populist attitudes on the NFM perception via social media news use, while accounting for the control variables included in the OLS models. Mediation analysis was run with PROCESS macro, Model 4 in SPSS (Hayes, 2018).

\subsection{Case Selection}

To assess the explanatory power of our analytical model and the generalizability of our findings, we selected two

Table 2. Individual items for populist attitudes by country.

\begin{tabular}{lcc}
\hline Populist Statements & $\begin{array}{c}\text { Italy } \\
\text { Mean (SD) }\end{array}$ & $\begin{array}{c}\text { Portugal } \\
\text { Mean (SD) }\end{array}$ \\
\hline "The politicians in the Parliament need to follow the will of the people." & $4.24(0.82)$ & $4.26(0.87)$ \\
$\begin{array}{l}\text { "The people, and not the politicians, should make the most important } \\
\text { political decisions." }\end{array}$ & $3.68(1.08)$ & $3.39(1.22)$ \\
"I would rather be represented by an ordinary citizen than by a & $3.40(1.17)$ \\
$\begin{array}{l}\text { professional politician." } \\
\text { "The political differences between the elite and the people are larger }\end{array}$ & $3.77(0.92)$ \\
$\begin{array}{l}\text { than the differences among the people." } \\
\text { "Elected officials talk too much and take too little action." }\end{array}$ & $4.24(0.89)$ \\
"What people call 'compromise' in politics is really just selling out on & $3.38(1.04)$ \\
one's principles." & $3.21)$
\end{tabular}

Note: SD = Standard Deviation. 
Southern European cases that clearly diverge in terms of their party system characteristics and the articulation of populist attitudes. After the demise of the First Republic, Italy witnessed the emergence and success of several political parties articulating populist discourses (Verbeek \& Zaslove, 2016). Two of these parties, the M5S and the Lega, became the two most voted for parties in the 2018 general elections, and they even managed to build a coalition government that lasted until 2021 (D'Alimonte, 2019). By contrast, in Portugal, the traditional party system showed a striking resilience in the face of the Great Recession. Mainstream center-right and center-left political parties remained the central players in the Portuguese party system and continued to play dominant roles in national and regional political institutions. Furthermore, as previous comparative analyses have shown, Portuguese political parties failed to articulate strong populist discursive elements (Lisi \& Borghetto, 2018). Therefore, Portugal and Italy present the most extreme and contrasting positions in terms of populist activation and party system change among Southern European countries. By analyzing these two very different countries, we can assess the degree to which the associations we are putting to test are contextdependent or stable across cases. Furthermore, we think that the inclusion of the Portuguese case provides our study with additional analytical leverage. We simply cannot discard the possibility that a low level of activation of populist political discourses limits the associations between populist attitudes and the informative uses of social media: Populist political discourses do not merely concern electoral competition and party-voter linkages, but they are also related to a wider set of social behaviors and cultural orientations. More specifically, to the extent that populist political discourses shape and interact with other social attitudes, we could expect Portugal to have a lower probability of displaying a structured pattern of association between populist attitudes, social media news use, and NFM. Finding empirical evidence of any or all these associations in this less-likely case would therefore render strong support for the generalizability of the expectations that guide this article.

\section{Results}

The results of our first OLS regression model (Table 3) show that individuals with stronger populist attitudes tend to consume more news in social media in Italy $(\beta=.065, p<.05)$. The coefficient for populist attitudes almost reaches statistical significance in the pooled models $(\beta=.042, p<.10)$, and the relationship does not reach statistical significance in Portugal $(\beta=.007, p>.10)$. Therefore, and in line with previous research, we find no clear connection between populist attitudes and social media news use that is consistent across countries (RQ1). To delve into this relationship, we tested whether populist attitudes would predict news use on any social media platforms included in our construct

Table 3. OLS regression Model 1-predicting social media news use.

\begin{tabular}{|c|c|c|c|}
\hline \multirow[b]{2}{*}{ Predictors } & \multicolumn{3}{|c|}{ Social Media News Use } \\
\hline & Italy & Portugal & Pooled Countries \\
\hline \multicolumn{4}{|l|}{ Block 1: Demographics } \\
\hline Sex $($ female $=1)$ & $.073 * *$ & .035 & $.070 * * *$ \\
\hline Age & $-.181 * * *$ & $-.228 * * *$ & $-.198 * * *$ \\
\hline Education & -.039 & -.030 & $-.058 * *$ \\
\hline Household Income & $-.115^{* * *}$ & -.054 & -.042 \\
\hline$\Delta R^{2}$ & $3.3 \%$ & $2.9 \%$ & $2.5 \%$ \\
\hline \multicolumn{4}{|c|}{ Block 2: Political Antecedents } \\
\hline Ideology & $.077^{*}$ & .033 & $.080 * *$ \\
\hline Political Trust & .049 & -.008 & .022 \\
\hline Political Interest & .034 & .057 & .028 \\
\hline$\Delta R^{2}$ & $2.5 \%$ & $1.6 \%$ & $1.9 \%$ \\
\hline \multicolumn{4}{|c|}{ Block 3: Media Antecedents } \\
\hline Trad. News Use & $.307 * * *$ & $.277^{* * *}$ & $.302 * * *$ \\
\hline$\Delta R^{2}$ & $8.2 \%$ & $6.6 \%$ & $7.9 \%$ \\
\hline \multicolumn{4}{|c|}{ Block 4: Variable of Interest } \\
\hline Populist Attitudes & $.065^{*}$ & .007 & $.042^{\#}$ \\
\hline$\Delta R^{2}$ & $0.3 \%$ & $0.00 \%$ & $0.1 \%$ \\
\hline Total $R^{2}$ & $14.2 \%$ & $11.1 \%$ & $12.5 \%$ \\
\hline
\end{tabular}

Notes: Sample size: Italy = 1,000; Portugal = 1,055; pooled countries = 2,055. Cell entries are OLS standardized Beta $(\beta)$ coefficients.

\# $p<.10 ; * p<.05 ; * * p<.01 ; * * *<<.001$. 
(results provided in Table 4), using the same controls as in Table 3 (Model 1). In line with previous research, we find that stronger populist attitudes predict a more frequent use of Facebook for news $(\beta=.09, p<.001)$. Conversely, the relationship between populist attitudes and Twitter use for news is negative $(\beta=-.053, p<.05)$.

Results included in Table 5, Model 2 (M2) evidence the existing connection between populist attitudes and NFM (H1). Individuals ranking higher on populist attitudes show greater levels of NFM using data from
Italy $\left(\beta=.125, p<.001\right.$, total $\left.R^{2}=12.3 \%\right)$, Portugal ( $\beta=.063, p<.05$, total $\left.R^{2}=11.6 \%\right)$, and the pooled model $(\beta=.096, p<.001)$. Among the controls, we see a consistent positive effect of political trust $(\beta=.116$, $p<.001$; more trusting individuals rank higher on NFM) and social media news use $(\beta=.268, p<.01$; using more social media for news predicts higher levels of NFM). Political interest negatively predicts NFM $(\beta=-.126$, $p=.001$ ), denoting that those more interested in politics will not share that the news will find them without active

Table 4. OLS regressions-predicting SM platforms.

\begin{tabular}{lcccc}
\hline & \multicolumn{3}{c}{ Pooled Countries } \\
\cline { 2 - 5 } Predictors & Facebook & Twitter & WhatsApp & Other SM platforms \\
\hline Populist Attitudes & $.09 * * *$ & $-.053^{*}$ & .024 & .02 \\
$\Delta R^{2}$ & $0.7 \%$ & $0.2 \%$ & $0 \%$ & $0 \%$ \\
Total $R^{2}$ & $6 \%$ & $5.4 \%$ & $7.4 \%$ & $9.9 \%$ \\
Controls & $\checkmark$ & $\checkmark$ & $\checkmark$ & $\checkmark$ \\
\hline
\end{tabular}

Notes: Sample size: 2,055 . Cell entries are OLS standardized Beta $(\beta)$ coefficients. ${ }^{\#} p<.10 ;{ }^{*} p<.05 ;{ }^{* *} p<.01 ;^{* * *} p<.001$.

Table 5. OLS regression Models 2 and 3-predicting News Finds Me perception.

\begin{tabular}{|c|c|c|c|c|c|c|}
\hline \multirow[b]{2}{*}{ Predictors } & \multicolumn{6}{|c|}{ News Finds Me Perception } \\
\hline & $\begin{array}{l}\text { Italy } \\
\text { (M2) }\end{array}$ & $\begin{array}{l}\text { Italy } \\
\text { (M3) }\end{array}$ & $\begin{array}{l}\text { Portugal } \\
\text { (M2) }\end{array}$ & $\begin{array}{l}\text { Portugal } \\
\text { (M3) }\end{array}$ & $\begin{array}{c}\text { Pooled } \\
\text { Countries (M2) }\end{array}$ & $\begin{array}{c}\text { Pooled } \\
\text { Countries (M3) }\end{array}$ \\
\hline \multicolumn{7}{|l|}{ Block 1: Demographics } \\
\hline Sex $($ female $=1)$ & -.027 & -.033 & -.035 & $-.057^{\#}$ & -.028 & $-.039^{\#}$ \\
\hline Age & $.131 * * *$ & $.121 * * *$ & $-.089 * * *$ & $-.070 *$ & -.021 & -.025 \\
\hline Education & $-.095 * *$ & $-.096 * * *$ & -.019 & -.006 & -.033 & -.029 \\
\hline Household Income & -.003 & -.013 & -.019 & -.021 & -.018 & -.022 \\
\hline$\Delta R^{2}$ & $2.9 \%$ & $2.9 \%$ & $2.6 \%$ & $2.6 \%$ & $0.6 \%$ & $0.6 \%$ \\
\hline \multicolumn{7}{|c|}{ Block 2: Political Antecedents } \\
\hline Ideology & $.072 *$ & $.072 *$ & .013 & .031 & $.051^{*}$ & $.060 * *$ \\
\hline Political Trust & $.098 * *$ & $.102 * *$ & $.115^{* * *}$ & $.121 * * *$ & $.116 * * *$ & $.120 * * *$ \\
\hline Political Interest & $-.111^{* *}$ & $-.103 * *$ & $-.129 * * *$ & $-.117 * * *$ & $-.126 * * *$ & $-.120 * * *$ \\
\hline$\Delta R^{2}$ & $1.9 \%$ & $1.9 \%$ & $1.5 \%$ & $1.5 \%$ & $2 \%$ & $2 \%$ \\
\hline \multicolumn{7}{|l|}{ Block 3: Media Antecedents } \\
\hline Trad. News Use & -.049 & $-.063^{\#}$ & -.043 & $-.072 *$ & $-.049 *$ & $-.063 * *$ \\
\hline SM News Use (5 items) & $.258 * * *$ & - & $.280 * * *$ & - & $.275^{* * *}$ & - \\
\hline SM News Use ( 1 item) & - & $.131^{* *}$ & - & $.246 * * *$ & - & $.177^{* * *}$ \\
\hline Facebook & - & $.111^{* *}$ & - & .033 & - & $.090 * *$ \\
\hline Twitter & - & $.092 * *$ & - & $-.065^{*}$ & - & .024 \\
\hline WhatsApp & - & $.094 *$ & - & .051 & - & $.076 * *$ \\
\hline Others & - & -.059 & - & $.095^{*}$ & - & .012 \\
\hline$\Delta R^{2}$ & $6.3 \%$ & $7.5 \%$ & $7.1 \%$ & $9.9 \%$ & $7 \%$ & $8.3 \%$ \\
\hline \multicolumn{7}{|l|}{ Block 4: Variable of Interest } \\
\hline Populist Attitudes & $.125 * * *$ & $.121 * * *$ & $.063^{*}$ & .050 & $.096 * * *$ & $.089 * * *$ \\
\hline$\Delta R^{2}$ & $1.3 \%$ & $1.2 \%$ & $0.3 \%$ & $0.2 \%$ & $0.8 \%$ & $0.6 \%$ \\
\hline Total $R^{2}$ & $12.3 \%$ & $13.5 \%$ & $11.6 \%$ & $14.3 \%$ & $10.4 \%$ & $11.6 \%$ \\
\hline
\end{tabular}

Notes: Sample size: Italy = 1,000; Portugal = 1,055; pooled countries = 2,055. Cell entries are OLS standardized Beta $(\beta)$ coefficients. ${ }^{\#} p<.10 ; * p<.05 ; * * p<.01 ; * * * p<.001$. 
implication from their side. Consistent with prior studies, traditional news use is also negatively related to NFM ( $\beta=-.049, p<.05)$, meaning that those who consume news on TV, radio, and newspapers (online and offline) tend to believe less that the news will find them with no active effort. Social media news and traditional news use are rigorous controls for the relationship proposed, as they are strong predictors of NFM (Gil de Zúñiga et al.,

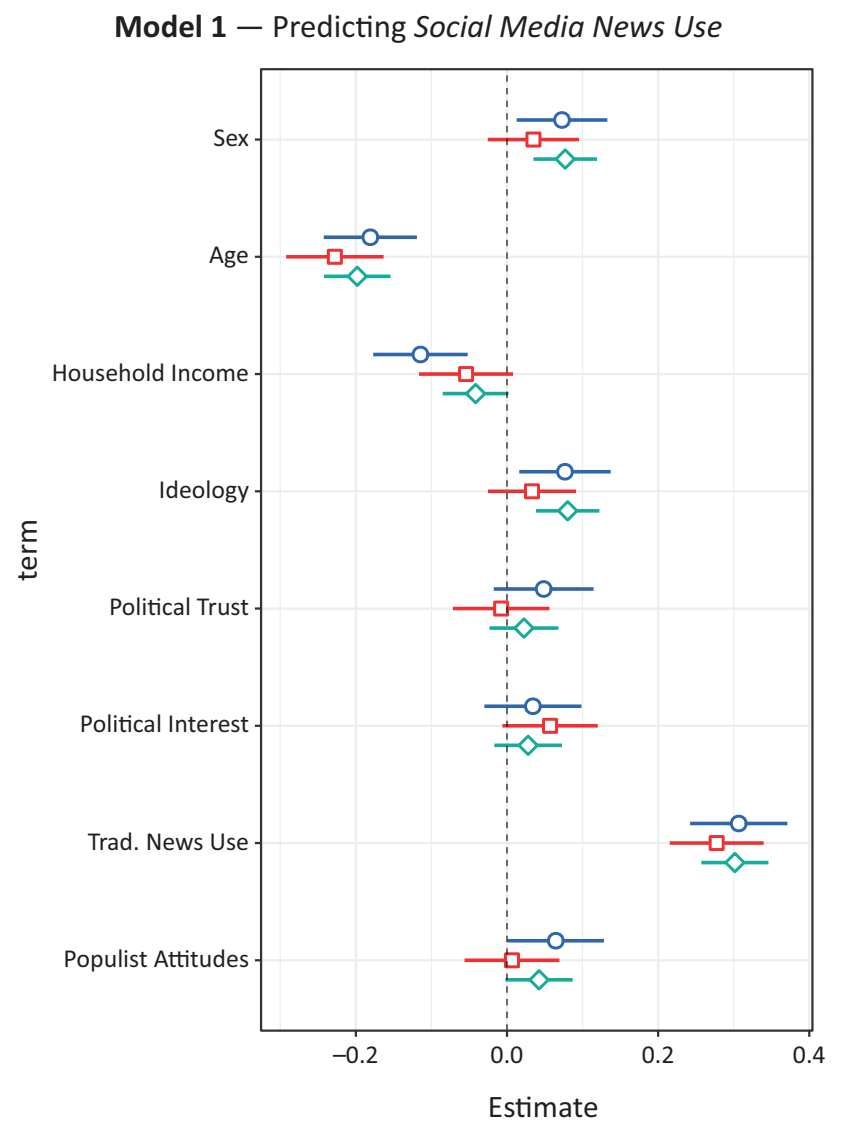

2017). Figure 1 provides a graphical representation of the results.

Finally, mediation analysis over pooled data reveals an indirect effect of populist attitudes on the NFM through social media news use (5 items, $\beta=.029$, $s e=.017,95 \% \mathrm{Cl}=[.002-.059])$. Figure 2 shows the direct and indirect paths, based on the OLS regression unstandardized coefficients reported by PROCESS macro (Hayes,

Model 2 - Predicting News Finds Me Perception

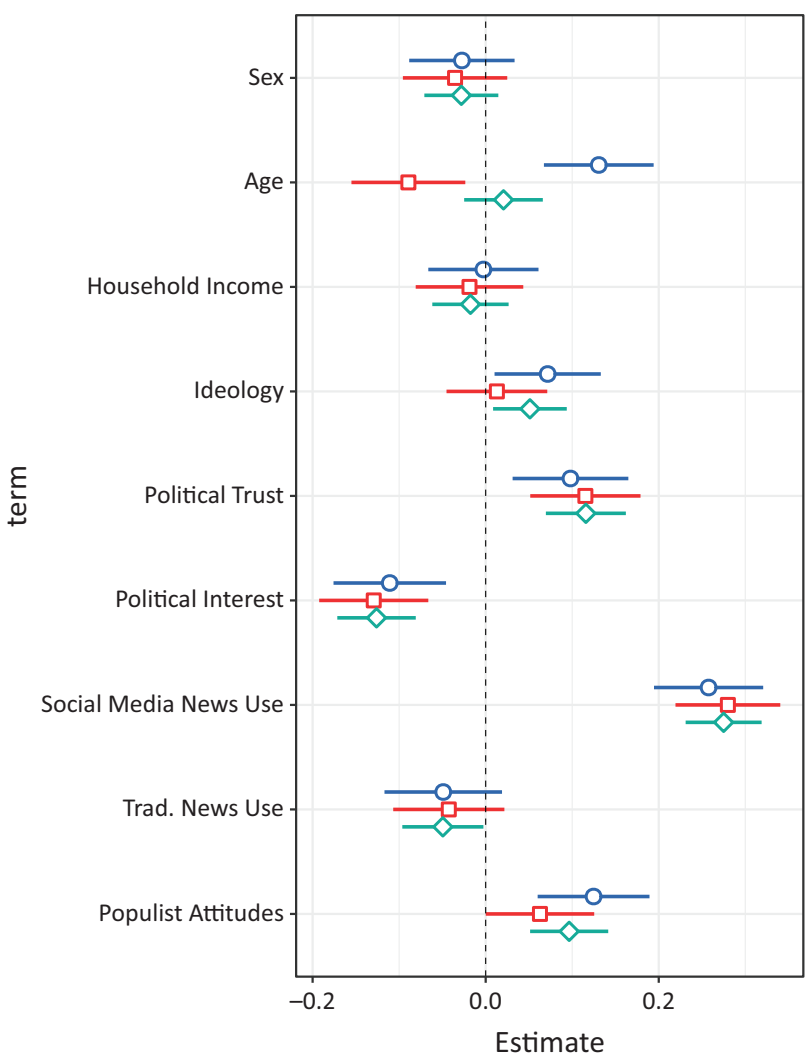

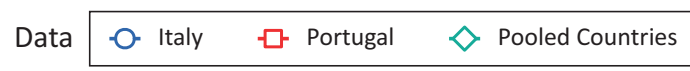

Figure 1. Visualization for OLS regressions in Italy, Portugal, and pooled countries' data. Note: Figure is based on the OLS standardized Beta $(\beta)$ coefficients (95\% Confidence Interval) from Tables 3 and 5.

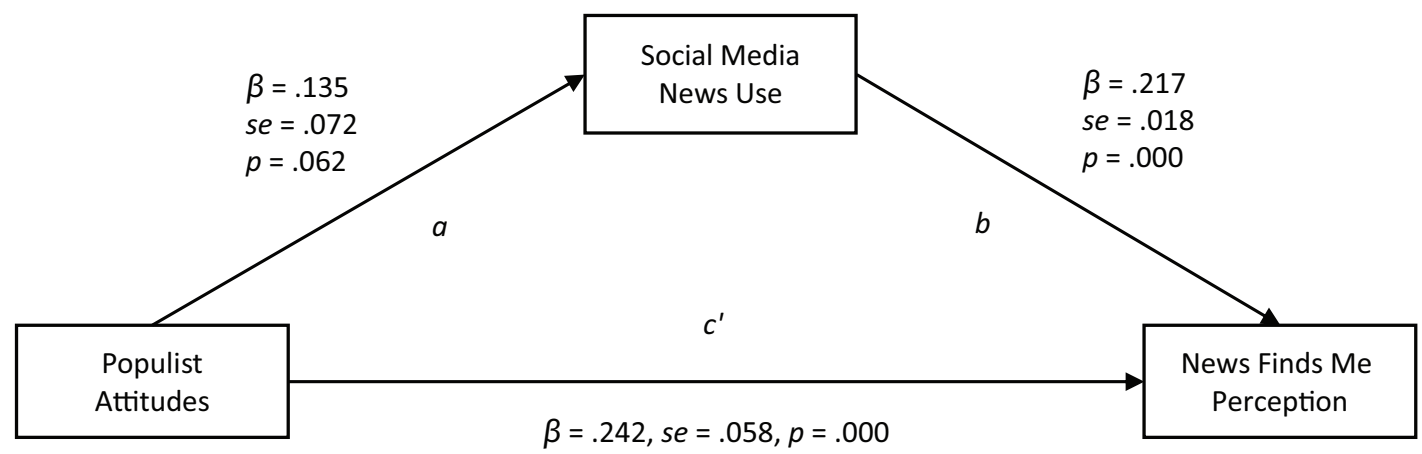

Figure 2. Mediation analysis for Portugal and Italy pooled data. Notes: Sample size $=2,055$. Path cells are unstandardized coefficients. Bootstrap samples for $\mathrm{Cl}: 5,000$ simulations. The model includes the same controls and predictors as Model 2 (Table 5). The point estimate of the indirect effect $(\mathrm{a} \times \mathrm{b})$ is .029 , se $=.017,95 \% \mathrm{Cl}=[.002-.059]$; and of the total effect (c) is .272 , se $=.060,95 \% \mathrm{Cl}=[.173-.370] . \mathrm{Cl}=$ confidence interval. 
2018). The mediating mechanism can be read as people reporting populist attitudes further consume news in social media, which in turn explains the proliferation of NFM. Having populist attitudes positively relates to NFM, directly and indirectly. Table 6 provides a report on the mediation analyses conducted using each social media platform as a mediator variable. An indirect effect can be found with social media news use ( 1 item, $\beta=.039$, $s e=.016,95 \% \mathrm{Cl}=[.007-.072])$ and Facebook $(\beta=.054$, se $=.016,95 \% \mathrm{Cl}=[.024-.086])$.

\section{Discussion and Conclusion}

While initial theoretical expectations existed about a clear-cut relationship between populist attitudes and social media news use, this connection has proved to be more complex than expected. Individuals displaying stronger populist attitudes tend to use social media for news more often only in some countries and/or depending on the specific platforms considered as social media sources. Our results for RQ1 are in line with these findings, as we find a significant relationship in one of the countries (Italy) but not in Portugal nor in the pooled model. A possible explanation for it is the broad range of motivations behind social media news use, which is far from exclusive of populist individuals. However, it might also be a consequence of different understandings of social media, not all of which are along the lines of anti-elitism and people-centrism. In a nutshell, the antecedents and understandings of social media are likely to be too rich to be exhausted by the populist-social media connection.

Taking this into account and looking for a better understanding of how populist individuals interact with online environments, we hypothesized a positive association between populist attitudes and NFM. This relationship taps into the foundations of the populist-social media connection, as it combines anti-elitism, peoplecentrism, and the Manichean outlook. Still, it is more specific and seems to better refer to demand-side populism alone. In line with it, we find a positive association between populist attitudes and NFM that works in all tested models (Italy, Portugal, and the pooled model), confirming $\mathrm{H} 1$. Notably, the effect remains even after controlling for powerful predictors of NFM such as demographics, political antecedents, and social media and traditional news use. Furthermore, in response to RQ2, we find that part of the association between populist attitudes and NFM is mediated by social media news use, which indicates the effects of populist attitudes on social media use may be less direct than initially expected. In fact, such a mediating mechanism entails that populist individuals who use social media for news could develop the perception that the news will find them. While this is true for any social media user, populist attitudes seem to increase the chances of developing a "passive" way of approaching the consumption of new information, which might foster a misperception of how one is informed, followed by a decrease in political knowledge and/or interest (Gil de Zúñiga \& Diehl, 2019). In a nutshell,

Table 6. Mediation analysis-Comparison between social media platforms.

\begin{tabular}{|c|c|c|c|}
\hline Mediator & Beta & $S E$ & $95 \% \mathrm{Cl}$ \\
\hline \multicolumn{4}{|c|}{ Social Media News Use (5 items) } \\
\hline Direct Effect & .242 & .058 & $.147-.339$ \\
\hline Indirect Effect & .029 & .017 & $.002-.059$ \\
\hline \multicolumn{4}{|c|}{ Social Media News Use (1 item) } \\
\hline Direct Effect & .233 & .058 & $.119-.347$ \\
\hline Indirect Effect & .039 & .016 & $.007-.072$ \\
\hline \multicolumn{4}{|l|}{ Facebook } \\
\hline Direct Effect & .217 & .058 & $.103-.332$ \\
\hline Indirect Effect & .054 & .016 & $.024-.086$ \\
\hline \multicolumn{4}{|l|}{ Twitter } \\
\hline Direct Effect & .286 & .060 & $.169-.403$ \\
\hline Indirect Effect & -.015 & .008 & $-.033-.000$ \\
\hline \multicolumn{4}{|l|}{ WhatsApp } \\
\hline Direct Effect & .262 & .059 & $.146-.377$ \\
\hline Indirect Effect & .016 & .011 & $-.010-.032$ \\
\hline \multicolumn{4}{|c|}{ Other SM platforms } \\
\hline Direct Effect & .263 & .059 & $.148-.379$ \\
\hline Indirect Effect & .008 & .011 & $-.012-.030$ \\
\hline
\end{tabular}

Notes: $\mathrm{N}=2,055$. Unstandardized coefficients. $\mathrm{Cl}=$ Confidence Interval. Significance level $=95 \%$. 
populist attitudes seem to condition how social media news is consumed, rather than the absolute amount. This distinct engagement with politics on social media that more populist individuals show may have relevant consequences that translate into the offline realm, too (crucially, on different forms of political behavior).

Our article is a first attempt to explore the association between populist attitudes and NFM. By doing that, it contributes to a larger stream of literature revolving around the populism-social media connection. However, our approach does not come without limitations, and four main aspects must be mentioned here. First, we build upon the operationalization of populist attitudes by Akkerman et al. (2014). While this is among the most widespread measures of populist attitudes in social sciences, and despite its theoretical and empirical usefulness (Silva et al., 2020), it is not the only operationalization available. As differences exist depending on how populist attitudes are measured (Silva et al., 2020), further studies will be needed to confirm our results. Second, our comparative study focuses on two countries of Southern Europe. We believe our main findings should hold with data for other countries, but that remains a theoretical conjecture until further cross-cultural studies empirically confirm it. Third, we theorize a causal path from populist attitudes to social media news use and NFM, but mutual reinforcing dynamics likely exist between these variables. Since our findings are drawn upon cross-sectional data, we cannot empirically ascertain the direction of the relationship. Studies using longitudinal data will be particularly useful to put our assumptions and results to an additional empirical test. Lastly, our indicators of social media news use consider respondents' frequency of use but do not capture nuances regarding the type of news. Further studies considering this variation will not only matter to satisfy academic curiosity. In fact, understanding populists' media diets is of the highest relevance to unravel the democratic consequences of widespread populist attitudes.

\section{Acknowledgments}

Late stages of this work at the Democracy Research Unit (DRU) have benefited from the support of the Spanish National Research Agency's Program for the Generation of Knowledge and the Scientific and Technological Strengthening Research + Development Grant PID2020115562GB-I00. Responsibility for the information and views set out in this study lies entirely with the authors. The last author is funded by the "Beatriz Galindo Program" from the Spanish Ministry of Science, Innovation \& Universities, and the Junta de Castilla y León.

\section{Conflict of Interests}

The authors declare no conflict of interests.

\section{Supplementary Material}

Supplementary material for this article is available online in the format provided by the author (unedited).

\section{References}

Akkerman, A., Mudde, C., \& Zaslove, A. (2014). How populist are the people? Measuring populist attitudes in voters. Comparative Political Studies, 47(9), 1324-1353. https://doi.org/10/f6dp5p

Aslanidis, P. (2015). Is populism an ideology? A refutation and a new perspective. Political Studies, 64(1), 88-104.

Baker, R., Blumberg, S. J., Brick, J. M., Couper, M. P., Courtright, M., Dennis, J. M., Dillman, D., Frankel, M. R., Garland, P., Groves, R. M., Kennedy, C., Krosnick, J., Lavrakas, P. J., Lee, S., Link, M., Piekarski, L., Rao, K., Thomas, R. K., \& Zahs, D. (2010). AAPOR report on online panels. The Public Opinion Quarterly, 74(4), 711-781. https://doi.org/10/d5b644

Bucy, E. P., Foley, J. M., Lukito, J., Doroshenko, L., Shah, D. V., Pevehouse, J. C., \& Wells, C. (2020). Performing populism: Trump's transgressive debate style and the dynamics of Twitter response. New Media \& Society, 22(4), 634-658. https://doi.org/10/ggx49x

Caiani, M., \& Graziano, P. (2019). Understanding varieties of populism in times of crises. West European Politics, 42(6), 1141-1158. https://doi.org/10/ gh3hwk

Canovan, M. (2004). Populism for political theorists? Journal of Political Ideologies, 9(3), 241-252. https:// doi.org/10/c485sx

Conselho Nacional de Educação. (n.d.). Conselho Nacional de Educação. https://www.cnedu.pt/pt

D'Alimonte, R. (2019). How the populists won in Italy. Journal of Democracy, 30(1), 114-127. https://doi. org/10/gg5sx9

Dornbusch, R., \& Edwards, S. (1991). The macroeconomics of populism. In R. Dornbusch \& S. Edwards (Eds.), The macroeconomics of populism in Latin America (pp. 7-13). University of Chicago Press.

Eekhout, I., de Vet, H. C. W., Twisk, J. W. R., Brand, J. P. L., de Boer, M. R., \& Heymans, M. W. (2014). Missing data in a multi-item instrument were best handled by multiple imputation at the item score level. Journal of Clinical Epidemiology, 67(3), 335-342. https:// doi.org/10/f5rpc9

Elchardus, M., \& Spruyt, B. (2016). Populism, persistent republicanism and declinism: An empirical analysis of populism as a thin ideology. Government and Opposition, 51(1), 111-133. https://doi.org/10/gf2wm9

Engesser, S., Ernst, N., Esser, F., \& Büchel, F. (2017). Populism and social media: How politicians spread a fragmented ideology. Information, Communication \& Society, 20(8), 1109-1126. https://doi.org/10/ gc7mxr

Ernst, N., Blassnig, S., Engesser, S., Büchel, F., \& Esser, F. 
(2019). Populists prefer social media over talk shows: An analysis of populist messages and stylistic elements across six countries. Social Media + Society, 5(1). https://doi.org/10/gh5fzt

Fawzi, N. (2019). Untrustworthy news and the media as "enemy of the people?" How a populist worldview shapes recipients' attitudes toward the media. International Journal of Press/Politics, 24(2), 146-164. https://doi.org/10.1177/1940161218811981

Fawzi, N., \& Mothes, C. (2020). Perceptions of media performance: Expectation-evaluation discrepancies and their relationship with media-related and populist attitudes. Media and Communication, 8(3), 335-347. https://doi.org/10.17645/mac.v8i3.3142

Gil de Zúñiga, H., \& Cheng, Z. (2021). Origin and evolution of the News Finds Me perception: Review of theory and effects. El Profesional de La Información, 30(3), Article e300321. https://doi.org/10/gkzfnw

Gil de Zúñiga, H., \& Diehl, T. (2019). News finds me perception and democracy: Effects on political knowledge, political interest, and voting. New Media \& Society, 21(6), 1253-1271. https://doi.org/ 10/gfpnmz

Gil de Zúñiga, H., Koc Michalska, K., \& Römmele, A. (2020). Populism in the era of Twitter: How social media contextualized new insights into an old phenomenon. New Media \& Society, 22(4), 585-594. https://doi.org/10/gkzpt5

Gil de Zúñiga, H., Weeks, B., \& Ardèvol-Abreu, A. (2017). Effects of the news-finds-me perception in communication: Social media use implications for news seeking and learning about politics. Journal of ComputerMediated Communication, 22(3), 105-123. https:// doi.org/10/gbhtc7

Gómez-Reino, M., \& Plaza-Colodro, C. (2018). Populist Euroscepticism in Iberian party systems. Politics, 38(3), 344-360. https://doi.org/10/gdw72c

Gottschall, A. C., West, S. G., \& Enders, C. K. (2012). A comparison of item-level and scale-level multiple imputation for questionnaire batteries. Multivariate Behavioral Research, 47(1), 1-25. https://doi.org/ 10/gfrkjg

Groshek, J., \& Koc-Michalska, K. (2017). Helping populism win? Social media use, filter bubbles, and support for populist presidential candidates in the 2016 US election campaign. Information, Communication \& Society, 20(9), 1389-1407. https://doi.org/ 10/gc7m $2 \mathrm{~h}$

Hawkins, K., Carlin, R., Littvay, L., \& Kaltwasser, C. R. (2019). The ideational approach to populism. Concept, theory, and analysis. Routledge.

Hawkins, K., \& Kaltwasser, C. R. (2017). What the (ideational) study of populism can teach us, and what it can't. Swiss Political Science Review, 23(4), 526-542. https://doi.org/10/gh4pnq

Hawkins, K., Kaltwasser, C. R., \& Andreadis, I. (2019). The activation of populist attitudes. Government and Opposition, 55(2), 283-307.
Hawkins, K., Riding, S., \& Mudde, C. (2012). Measuring populist attitudes. Committee on Concepts and Methods.

Hayes, A. F. (2018). Introduction to mediation, moderation, and conditional process analysis: A regressionbased approach (2nd ed.). Guilford Publications.

Instituto Nacional de Estatística. (n.d.). Statistics Portugal-Web Portal. https://www.ine.pt

Ionescu, G., \& Gellner, E. (1969). Populism: Its meanings and national characteristics. Weidenfeld and Nicolson.

Istituto Nazionale di Statistica. (n.d.). Istat.it. https:// www.istat.it

Jeroense, T., Luimers, J., Jacobs, K., \& Spierings, N. (2021). Political social media use and its linkage to populist and postmaterialist attitudes and vote intention in the Netherlands. European Political Science. Advance online publication. https://doi.org/10.1057/s41304020-00306-6

Kaltwasser, C. R., \& Van Hauwaert, S. M. (2020). The populist citizen: Empirical evidence from Europe and Latin America. European Political Science Review, 12(1), 1-18. https://doi.org/10/gjqkbk

Laclau, E. (2005). On populist reason. Verso.

Lisi, M., \& Borghetto, E. (2018). Populism, blame shifting and the crisis: discourse strategies in Portuguese political parties. South European Society and Politics, 23(4), 405-427. https://doi.org/10/ghz4vx

MacKay, D. J., \& Mac Kay, D. J. (2003). Information theory, inference and learning algorithms. Cambridge University Press.

Marcos-Marne, H. (2020). A tale of populism? The determinants of voting for left-wing populist parties in Spain. Political Studies, 69(4), 1053-1071.

Marcos-Marne, H. (2021). The effects of basic human values on populist voting. An analysis of 13 European democracies. Political Behavior. Advance online publication. https://doi.org/10/gh5fzr

Marcos-Marne, H., Llamazares, I., \& Shikano, S. (2021). Left-right radicalism and populist attitudes in France and Spain. Journal of Contemporary European Studies. Advance online publication. https://doi.org/10/ gkzfmx

Mudde, C. (2004). The populist zeitgeist. Government and Opposition, 39(4), 541-563. https://doi.org/10/ fj8jzb

Mudde, C., \& Kaltwasser, C. R. (2018). Studying populism in comparative perspective: Reflections on the contemporary and future research agenda. Comparative Political Studies, 51(13), 1667-1693. https://doi.org/ 10/gfhhb4

Müller, P., \& Schulz, A. (2021). Alternative media for a populist audience? Exploring political and media use predictors of exposure to Breitbart, Sputnik, and Co. Information, Communication \& Society, 24(2), 277-293. https://doi.org/10/gf6rsr

Rae, M. (2021). Hyperpartisan news: Rethinking the media for populist politics. New Media \& Society, 
23(5), 1117-1132. https://doi.org/10/gg7rb8

Reinemann, C., Aalberg, T., \& Esser, F. (2016). Populist political communication: Toward a model of its causes, forms, and effects. In T. Aalbert, F. Esser, C. Reinemann, J. Stromback, \& C. De Vreese (Eds.), Populist political communication in Europe (pp. 22-36). Routledge.

Rico, G., Guinjoan, M., \& Anduiza, E. (2017). The emotional underpinnings of populism: How anger and fear affect populist attitudes. Swiss Political Science Review, 23(4), 444-461. https://doi.org/10/gf3gz2

Rooduijn, M. (2019). State of the field: How to study populism and adjacent topics? A plea for both more and less focus. European Journal of Political Research, 58(1), 362-372. https://doi.org/10/gftggn

Schafer, J. L. (1999). Multiple imputation: A primer. Statistical Methods in Medical Research, 8(1), 3-15.

Schulz, A. (2019). Where populist citizens get the news: An investigation of news audience polarization along populist attitudes in 11 countries. Communication Monographs, 86(1), 88-111. https://doi.org/10/ ggspx6

Schulz, A., Müller, P., Schemer, C., Wirz, D. S., Wettstein, M., \& Wirth, W. (2018). Measuring populist attitudes on three dimensions. International Journal of Public Opinion Research, 30(2), 316-326. https://doi.org/ 10/gdqt3p

Schulz, A., Wirth, W., \& Müller, P. (2020). We are the people and you are fake news: A social identity approach to populist citizens' false consensus and hostile media perceptions. Communication Research, 47(2), 201-226. https://doi.org/10.1177/ 0093650218794854

Silva, B. C., Jungkunz, S., Helbling, M., \& Littvay, L. (2020). An empirical comparison of seven populist attitudes scales. Political Research Quarterly, 73(2), 409-424. https://doi.org/10/ghx8nm

Song, H., Gil de Zúñiga, H., \& Boomgaarden, H. G. (2020). Social media news use and political cynicism: Differential pathways through "news finds me" percep- tion. Mass Communication and Society, 23(1), 47-70. https://doi.org/10/gghenp

Stanley, B., \& Cześnik, M. (2021). Uninformed or informed populists? The relationship between political knowledge, socio-economic status and populist attitudes in Poland. East European Politics. Advance online publication. https://doi.org/10/gkzfjr

Stier, S., Kirkizh, N., Froio, C., \& Schroeder, R. (2020). Populist attitudes and selective exposure to online news: A cross-country analysis combining web tracking and surveys. The International Journal of Press/Politics, 25(3), 426-446. https://doi.org/10/ggr6z4

van Hauwaert, S. M., \& van Kessel, S. (2018). Beyond protest and discontent: A cross-national analysis of the effect of populist attitudes and issue positions on populist party support. European Journal of Political Research, 57(1), 68-92. https://doi.org/10/gcshv5

van Kessel, S., Sajuria, J., \& van Hauwaert, S. M. (2021). Informed, uninformed or misinformed? A crossnational analysis of populist party supporters across European democracies. West European Politics, 44(3), 585-610. https://doi.org/10/gjvtj5

Verbeek, B., \& Zaslove, A. (2016). Italy: A case of mutating populism? Democratization, 23(2), 304-323. https:// doi.org/10/ggb6rb

Wells, C., Shah, D., Lukito, J., Pelled, A., Pevehouse, J. C., \& Yang, J. (2020). Trump, Twitter, and news media responsiveness: A media systems approach. New Media \& Society, 22(4), 659-682. https://doi.org/10/ gj3frc

Weyland, K. (2001). Clarifying a contested concept: Populism in the study of Latin American politics. Comparative Politics, 34(1), 1-22.

Wright, K. B. (2005). Researching internet-based populations: Advantages and disadvantages of online survey research, online questionnaire authoring software packages, and web survey services. Journal of Computer-Mediated Communication, 10(3), Article JCMC1034. https://doi.org/10/d7z5cr

\section{About the Authors}

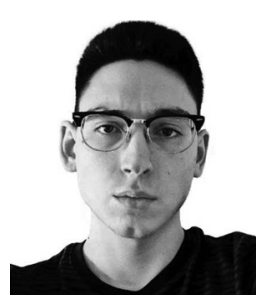

Pablo González-González is a doctoral student in political science at the University of Salamanca, and a member of the Democracy Research Unit (DRU). His research interests revolve around quantitative methods applied to political communication, social media, extremism, and political behavior.

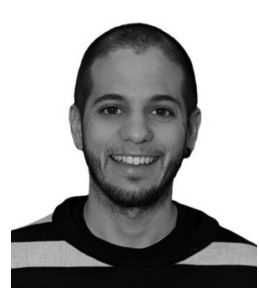

Hugo Marcos-Marné is an assistant professor at the Department of Political Science of the University of Salamanca (Spain), where he is also a member of the Democracy Research Unit (DRU). His research focuses on political behavior, attitudes, and national identities. He has published on these topics in Political Behavior, West European Politics, Politics, Political Studies, Electoral Studies, Journal of Contemporary European Studies, Journal of Ethnic and Migration Studies, Ethnicities, and National Identities, among others. 

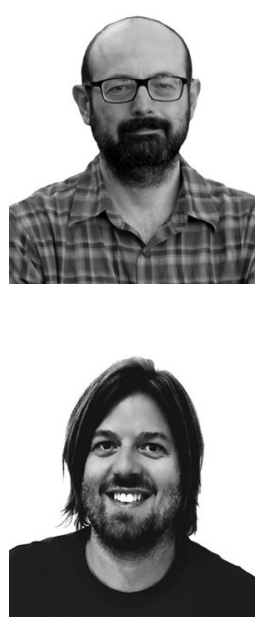

Iván Llamazares is a professor of political science at the University of Salamanca. He holds PhDs in political science from the University of North Carolina at Chapel Hill, and the Complutense University of Madrid. His research has focused on the study of political parties and behavior in Latin America and Europe.

Homero Gil de Zúñiga is a distinguished research professor at University of Salamanca and serves as director of the Democracy Research Unit (DRU). He is also a media effects professor at Pennsylvania State University, and senior research fellow at Universidad Diego Portales, Chile. Overall, the work that takes place at the DRU deals with the development of theoretically driven research, contributing to shed a social scientific light over social media and new technologies effects in the arena of political communication. 